\title{
Kitchen sink dramas: Women, modernity and space in Weimar Germany
}

DOI:

10.1191/1474474006cgj374oa

\section{Document Version}

Submitted manuscript

Link to publication record in Manchester Research Explorer

\section{Citation for published version (APA):}

Jerram, L. (2006). Kitchen sink dramas: Women, modernity and space in Weimar Germany. Cultural Geographies, 13(4), 538-556. https://doi.org/10.1191/1474474006cgj3740a

\section{Published in:}

Cultural Geographies

\section{Citing this paper}

Please note that where the full-text provided on Manchester Research Explorer is the Author Accepted Manuscript or Proof version this may differ from the final Published version. If citing, it is advised that you check and use the publisher's definitive version.

\section{General rights}

Copyright and moral rights for the publications made accessible in the Research Explorer are retained by the authors and/or other copyright owners and it is a condition of accessing publications that users recognise and abide by the legal requirements associated with these rights.

\section{Takedown policy}

If you believe that this document breaches copyright please refer to the University of Manchester's Takedown Procedures [http://man.ac.uk/04Y6Bo] or contact uml.scholarlycommunications@manchester.ac.uk providing relevant details, so we can investigate your claim.

\section{OPEN ACCESS}




\title{
Cultural Geographies \\ http://cgj.sagepub.com/
}

Kitchen sink dramas: women, modernity and space in Weimar Germany

Leif Jerram

Cultural Geographies 2006 13: 538

DOI: $10.1191 / 1474474006 \mathrm{cgj} 3740 a$

The online version of this article can be found at:

http://cgj.sagepub.com/content/13/4/538

\author{
Published by: \\ (9)SAGE \\ http://www.sagepublications.com
}

Additional services and information for Cultural Geographies can be found at:

Email Alerts: http://cgj.sagepub.com/cgi/alerts

Subscriptions: http://cgj.sagepub.com/subscriptions

Reprints: http://www.sagepub.com/journalsReprints.nav

Permissions: http://www.sagepub.com/journalsPermissions.nav

>> Version of Record - Oct 1, 2006

What is This? 


\title{
Kitchen sink dramas: women, modernity and space in Weimar Germany
}

\author{
Leif Jerram
}

School of History, University of Manchester

\begin{abstract}
This article uses historical evidence about the competing designs of kitchens in 1920s German social housing to argue that historians (and, to an extent, geographers) have overlooked the coercive capacity of space to compel certain forms of social relationship. Such has been the potency of the 'cultural' model in history and geography that the 'material' world has been cloaked by language and symbol. Bourgeois politicians, planners and reformers in 1920s Germany were not only compelled to think about domestic space for the poor for the first time, but had to actually produce the physical space if they wanted to make their ideologies 'live'. This article also shows that if we disaggregate the space of the home into its constituent parts (rather than simply contrasting the private and the public realms), different gender ideologies could be designed into domestic space, forcing families to adopt ways of living and patterns of sociability according to the priorities of, variously, 'Americanizers', socialists, conservatives and liberals. The kitchen designs of Frankfurt are well known, but in fact those of Munich were probably more widespread, and so this work further serves to decentre the canon of Modernism which dominates much discussion of Weimar building.
\end{abstract}

\begin{abstract}
A t the end of the First World War, Germany fell into a prolonged period of chaos and disorder. When this chaos and disorder found a coherent political voice, whether through socialism, communism, nationalism or Catholicism, it made it clear that social calm and political stability would be predicated on the capacity of the state to provide healthy, affordable housing in well-functioning cities. However, this left urban experts and governors across the new republic confronted by an imperative need to resolve a problem which frequently had a nebulous definition. In part emboldened by this volatility, violence and disorder, an expert class of governors and planners in German cities proposed a way of reforming the city and the citizen, by producing and applying a certain sort of knowledge about space, which would in turn create rational, orderly subjects to inhabit it.

This expert class responded to the demands underpinning urban political unrest by positing a new way of designing and living in homes. In doing so, they borrowed heavily from the discourse of 'scientific management' derived from US consumer goods industries. Up until that point much 'women's work' had not been susceptible to this management discourse, because it took place in the secret, obscure spaces of the home,
\end{abstract}


beyond the gaze (and often interest) of governors and experts. The imperative to produce housing exposed the domestic space of working-class families to public scrutiny, allowing male experts to prise open the socio-spatial domestic arrangements of a class which had, in the past, often been closed as tightly as a clam. By recasting the home as a site of labour and production, experts rightly recognized the enormous burden of domestic management which women carried, often alongside paid work outside the home. The dual nature of domestic spaces - as spaces of labour and work on the one hand, and familial sociability and leisure on the other - led to a contest amongst planners, governors, publicists, feminists and 'experts' in Germany and the USA about how best the rational state might intervene in them, in order to produce the ideal home, the ideal city, and the ideal citizen.

In German housing and planning policy, this contest crystallized around a discussion of what sort of female subject these improving projects of the helping, rational state would define. While some experts characterized the woman at home as worker, a productive citizen of the social state, other experts plotted her life as maternal and social. In the former model, the woman-at-home was to be scrutinized and organized in order to make her domestic labour efficient; in the latter, the woman was explicitly cast as invulnerable to rational scrutiny, and as responsible for the organization of her home herself. Crucially, rather than simply narrate and plot women's lives in advice literature, journals, visits by social workers or hygiene campaigns, both sets of experts set out to enforce their vision through the use of space. In particular, this article will focus on the room most associated with women's domestic labour: the kitchen. It will deal with the conflicting models for kitchen design offered by the city planners of Frankfurt and Munich in the 1920s, examining their links to the American models to which they were responding.

In examining these two competing spatial models, I pursue two arguments. First, space has been an under-recognized, under-analysed category in historical investigation. In particular, the role of physical spaces and physical barriers in enforcing social relationships and behaviours has been under-examined (and not just in historical scholarship), in favour of discussing the symbolic values of spaces, and these symbols' capacity to suggest social relationships and behaviours. ${ }^{1}$ Such symbolic value is of enormous importance, and has been examined to great profit by historians, but it is insufficient for understanding the force-relations inherent in spatial organization. ${ }^{2}$ Thus the spaces of a prison do not suggest imprisonment, by being the repositories of symbols or discourses of imprisonment. The spaces of a prison produce imprisonment; being locked in a prison cell is not metaphorically constraining, but literally. This difficulty in approaching space in its 'factual', material, coercive form is acute in both history and geography, and writers in both disciplines have struggled to relate to its materiality, especially since the 'cultural turn'. ${ }^{3}$ We need to recognize more clearly the dual nature of spaces - especially buildings, one of the primary technologies of spatial manipulation. Spaces are negotiated, contested constructs (like 'home'), but they are also material 'facts' that can compel - rather than simply suggest - certain responses. They can function as an index of some other investigative variable like class, gender, sociability or work; but in their material form they also can claim parity with 
those objects of investigation as a socially (and historically) structuring agent in their own right.

Secondly, I want to call into question a habit of historical enquiry which, when dealing with buildings, focuses on those which belong to a canon. This canon does not even have to include 'real' buildings and spaces; more ink has been spilled over the unbuilt panopticon than over all the spaces in all the prisons in this country. In the twentiethcentury German context, this has meant focusing again and again on the 'rise' of Modernism. This Modernism has been cast as the bold spirit of the true, liberal, creative Germany, the daring adventure of the humane social experiment that was Weimar, thwarted by the inhuman barbarity and stylistic kitsch of National Socialism. ${ }^{4}$ Recent work by the design historian Paul Betts argues that locating the 'true spirit' of Germany in radical Modernism was a major plank in West Germans' attempts to describe for themselves the democratic, humane society which they were attempting to construct. ${ }^{5}$ It allowed West Germans not only to locate for themselves a noble heritage before the NSDAP horror, but to surround themselves with the well-designed objects which represented that heritage, reinforcing the view that the Nazi catastrophe was a blip.

However, overwhelmingly most architecture and design in 1920s Germany was not Modernist. By habitually focusing on the exceptional, the rare and the experimental, architectural and design historians have overlooked the vast majority of spaces and environments which shaped the day-to-day lives not just of German citizens but of all humans. From our births in mediocre hospitals, through our education in average schools, to our family lives in unexceptional houses, our rites of passage are shaped by the banal, the inherited, the conventional. Although innovation happens, and while it can be important, we should not allow ourselves to be distracted by it at the expense of other more important and persistent phenomena. Furthermore, architecture and design historians have focused on the rhetoric of ambitions and aspirations of the producers of designs and spaces, frequently privileging architects' and experts' own hopes for a particular space over and above the actual effects which such a space might inevitably exert on its users. ${ }^{6}$

In short, while historians of the symbolic meanings ascribed to space have successfully focused on the banal, they have not dealt with the physical and the material. Those who have dealt with the physical and material have too readily confined themselves to narrating the 'rise' of something they particularly prize: Modernism. In doing so, they have overlooked the lived realities both of the buildings they describe and of the overwhelming number of unhistoricized buildings and spaces with which they rarely engage at all. Finally, as anthropologist Irene Cieraad has pointed out, when domestic space is problematized in academic discourse, it is often done as either a highly aggregated space or a highly exoticized one. What she means by this is that when scholars have focused on the disaggregated variety of spaces within homes and houses, they have generally located them in non-Western cultures. Meanwhile, when they have investigated domestic space in Western cultures, they have posited it as one homogeneous space, existing in a binary opposite: one coherent locus of the private, as opposed to the public. ${ }^{7}$ The dynamic interplay of intra-domestic spaces has been overlooked. 
Of the two models analysed here, one sits inside the Modernist canon and one outside it. The kitchens designed by the city of Frankfurt were placed in housing estates which exist comfortably in the Modernist narrative, and so have received some - albeit limited - scholarly attention. The counter-model proposed by the city of Munich has never, to my knowledge, received any attention anywhere, although ultimately it was used more frequently in German social housing projects (and in British ones after the war). ${ }^{8}$ The two models differ spatially in one crucial way. The Frankfurt planners, designers and experts abandoned the traditional German working-class arrangement of combining the social space of the family and the workplace of women together into the Wobnküche ('living room-cum-kitchen'). Instead, they divided the woman's work space from the woman's domestic social and leisure space with a wall (Figure 1). Munich's experts tried to borrow what they perceived as advantageous in discussions of efficiency, but they challenged the idea that women in their domestic social and work lives were in any way legitimate subjects of rational scrutiny. Instead, they used

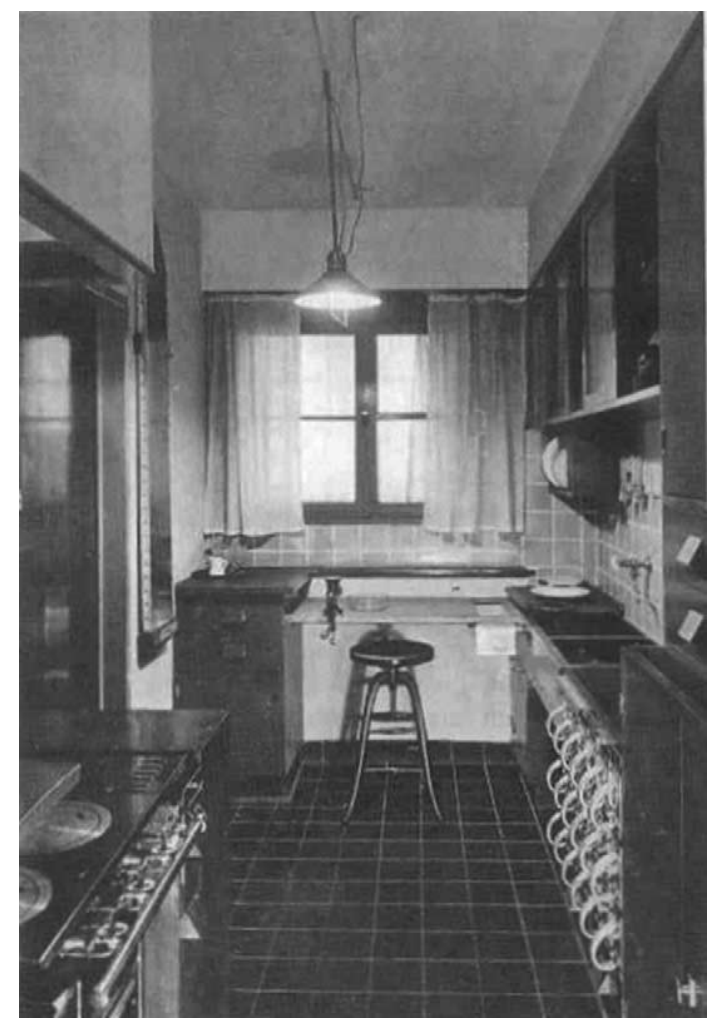

FIGURE 1 The Frankfurt kitchen, designed by Margarete Lihotzky, 1926. It is divided from the living room by the wall on the left. The jug-drawers (lower right), ready-labelled with the 'ideal' hygienic foodstuffs, proved particularly unpopular with housewives. The drawers named foods which they did not like, and did not have storage for potatoes. 
domestic space to enforce a union between the work and social life of the woman-athome (Figure 2). They preserved the union between work space and social space. It is these competing modernities which I want to explore. To do this, I need to establish the American parameters and paradigms which influenced Frankfurt's projects, because it was those parameters and paradigms which other experts - just as modern - wanted to disrupt and subvert.

\section{Woman as producer and consumer: the American heritage}

Two key decisions took place in Frankfurt which made such a radical reform of the working-class kitchen possible: first, the appointment by an ambitious socialist mayor, Ludwig Landmann, of Ernst May as chief city architect and planner, charged with developing a high-volume, low-cost housing strategy. His first major act in office was the second key decision: he hired Grete Schütte-Lihotzky, whom he had in his earlier career poached from Vienna city council, where she had designed an all-in-one kitchen and bathroom, in which a worktop folded down over the bathtub.

May was fascinated by scientific management's productivity benefits, and its capacity to free up 'leisure time' for workers, and instituted conveyor-belt production facilities of

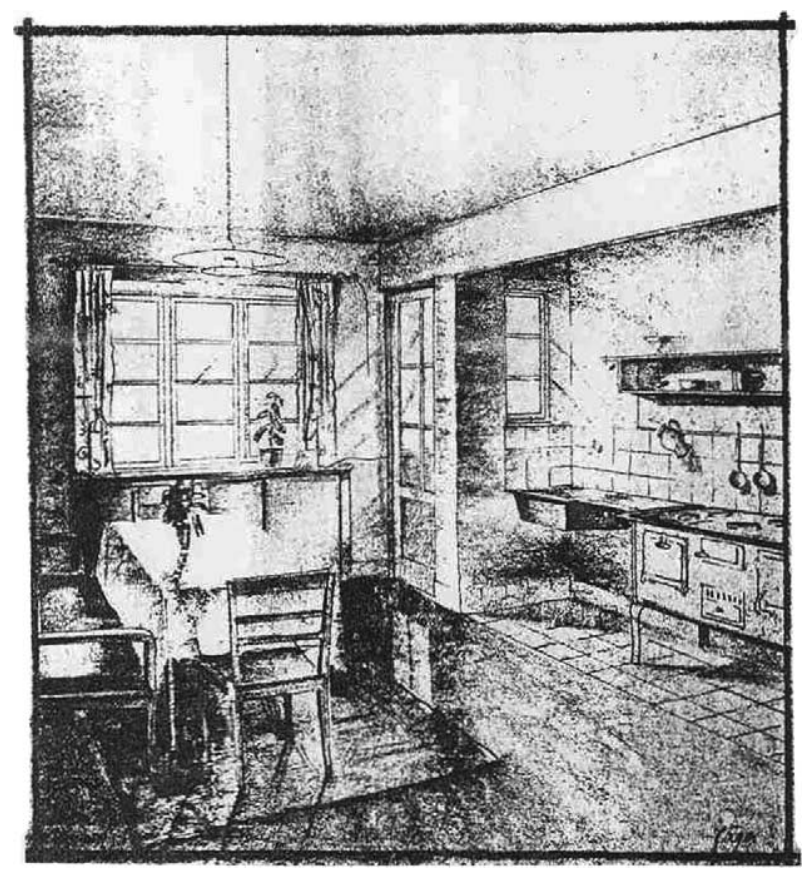

FIGURE 2 The Munich kitchen, c. 1928, probably designed by Building officer Karl Meitinger. Importantly, it forcibly unites women's work and social spaces, according to working-class convention. 
standardized building components. ${ }^{10}$ What transformed debate on women's spaces was the publication of a book by an American self-styled feminist, Christine Frederick. In 1919 she published Household engineering: scientific management in the bome. ${ }^{11}$ The translator into German was Irene Witte, the woman who, along with Erna Meyer, introduced the American ideology of the fitted kitchen to Lihotzky - and countless other Germans - and who planted the idea in Lihotzky's head that women in their domestic lives might be subject to the same sort of rational scrutiny usually reserved for optimizing capitalist productivity. ${ }^{12}$ Lihotzky equated rationalization with liberation, and this allowed what was an essentially very highly regulated and deterministic set of manipulations of women's lives and space to be couched in heroic rhetoric. Lore Kramer has identified a crossover between the work of Christine Frederick and a longer tradition of American, patrician middle-class feminism dating back to Catharine Beecher in the mid-nineteenth century. ${ }^{13}$

Beecher is credited with being at the intellectual and ideological core of the trend known as 'the cult of domesticity'. ${ }^{14}$ Beecher is remarkable not just for her formulations of what it meant to be a woman, and the rights and obligations it implied, but for her linkage of these to what it meant to be a housewife in an ill-planned kitchen, placing women's work and women's space at the heart of any understanding of women's social existence. ${ }^{15}$ Her formulations of what a kitchen should be were intimately bound up with her attempts to establish a discourse of home economics, the female, domestic and private version of that great nineteenth-century male, public theme of political economy. Beecher saw in housework the most terrible, confining drudgery for women and sought to find relief for it, and her rhetoric of boredom, oppression and fatigue rings through all of Frederick's and Lihotzky's writings.

Beecher's two great works on this area showed that in kitchens where men worked favourite examples being the Mississippi paddle steamer and the mobile military camp kitchen - the organization was rational, the kitchen was small, and the equipment was to hand. But in kitchens where women worked as servants or as housewives the equipment was spaced so that the sink might quite possibly be in a different room to the stove, and the preparation areas of food tended to be a long way from storage, cooking and waste-disposal areas. In brief, kitchens designed by men for women were irrational and maximized work, thereby imprisoning women in a cycle of fatigue, while kitchens designed by men for men were highly rational and did not burden them. On the basis of the ship's galley kitchen, Beecher came up with the 'workshop kitchen', the first conception of the domestic fitted kitchen, planned and installed in one step. ${ }^{16}$ Beecher's campaigning had considerable impact in the United States, not least due to her followers' exploitation of the World's Fairs in Chicago in 1893 and St Louis in 1904 to showcase her kitchen plans.

As Mary Nolan has demonstrated, this American 'rational' approach to work had already had some impact on German industrial production in the 1900s, but became more generally popular in the immediate aftermath of the Great War. ${ }^{17}$ These practices were underpinned by an entire economic mode of thought and social operation, dominated by frequently mutually antagonistic 'gurus', Frederick Taylor, Henry Ford, Frank Gilbreth and Lillian Gilbreth. They sought to break down every action into its 
component parts, denying any continuity whatsoever to the most mundane of actions, dividing labour into its irreducible synchronous elements - called 'therbligs', or 'Gilbreth' backwards. ${ }^{18}$ At the same time that the housing debate was raging in Germany, this 'time and motion' discourse united with a new set of technologies to produce the ultimate flattening of time into space. The experiential time of human life, lived out in cycles of growth and seasons, was transformed into a set of spatial measurements and manipulable data. This new system of economic and industrial analysis did not just devalue time. According to Kern's famous thesis, time and space became conflated, and experiential, human, lifecycle time was banished. ${ }^{19}$

An example of such a new technology permitting the ever greater blurring of the time-space distinction was the chronocyclograph, a gadget invented by Frank and Lillian Gilbreth in 1918 (Figure 3). It worked to deploy new technologies to increase this collapse/conflation of the space-time distinction. Its functioning is described and illustrated by a 1940 book on the subject:
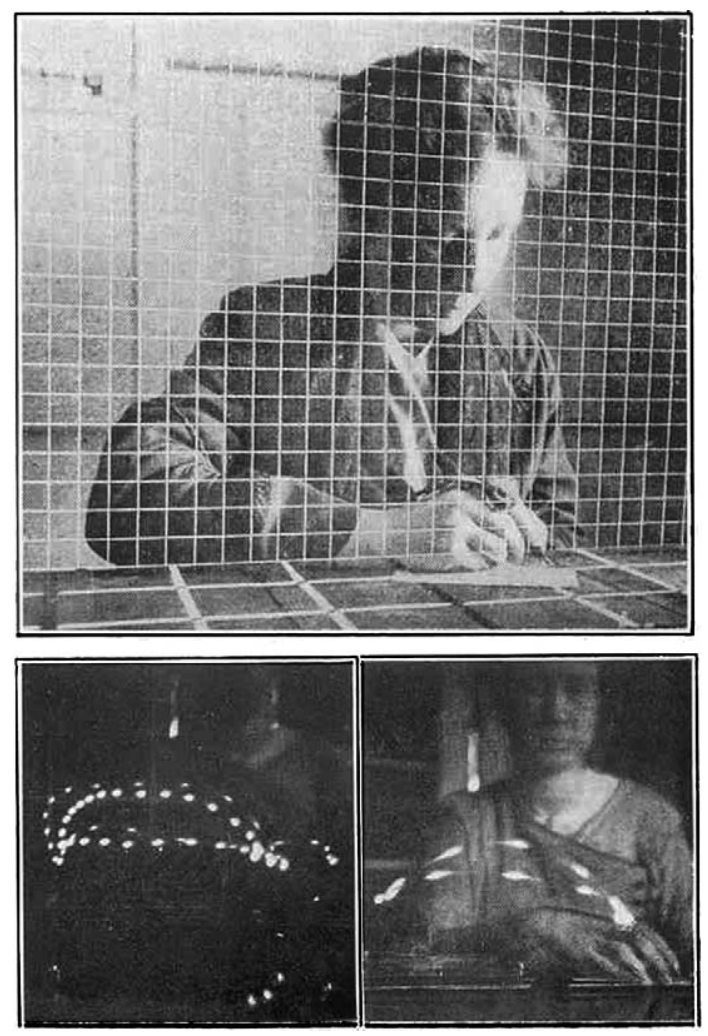

FIGURE 3 The chronocyclograph in action, mapping space and time into one set of statistics. Invented by Frank and Lilian Gilbreth, c. 1918. 
It is possible to record the path of motion of an operator in three dimensions by attaching a small electric light bulb to the fingers, hand or any other part of the body, and photographing, with a stereoscopic camera, the path of light as it moves through space. [With the introduction of variably flashing lights and time-lapse stereoscopic photography] it is possible to measure accurately time, speed, acceleration and retardation, and to show the path of motion in three dimensions. ${ }^{20}$

The individual's time and space were thus mapped onto a grid, where the operations could be transformed into a series of time-space statistics (matrixes) and subjected to intense expert scrutiny. As Lillian Gilbreth wrote in The homemaker and her job, 'We divide a process into operations, and these operations into cycles of motions, and these cycles of motions into elements of motions. ${ }^{21}$ The key feature of these motions is that they become synchronic or recombinant. They can be rearranged in any order to suit the productive needs of capitalism, and lose their affinities with the way that humans experience time as a unique, flowing series of events and experiences. In effect, one arrives at a situation of a stack of synchronic moments, the order of which is relevant only to the imperatives of capital optimization, rather than a row of unbroken diachronic experience for the person involved in manufacture. Not only is labour divided between members of society, but the divided labour of individuals has itself been scrutinized and redivided in the service of capitalist modes of production.

When Witte translated Household engineering: scientific management in the bome in 1922, this 12-part self-improvement course in how to be an efficient, productive housewife quickly became the bible of avant-garde German architects - May and Lihotzky in particular. In the book Frederick, as Beecher had done before her, suggested a way out of the 'treadmill' of domestic chores. Her solution, like Beecher's, was spatial: the end of the traditional Wobnküche, the usual arrangement in poorer homes which fused the social space of the dining and living area with the productive one of the cooking and food preparation area. Frederick described the near suicideinducing drudgery of housework, and how the threat of this might make women fear to enter - and hope to leave - the domestic sphere which was rightfully theirs. She viewed this as a threat to all civilization, and particularly the 'American way of life', its highest form. ${ }^{22}$

The key was the division of the home into a kitchen, where work was done, and the rest of the house, which was for the enjoyment of that new commodity, leisure. ${ }^{23}$ She provided a worked-out model of how the rational kitchen could introduce the woman to scientific management, and Figure 4 shows how this would function to reduce the walking time a woman would spend in the course of her work. The model for the newly divided kitchen was to be the man's world of industry: 'The bench of the mechanic can serve as a model for the kitchen.... The kitchen must follow this workshop ideal'. ${ }^{24}$ Just as the man left the home to go to his workshop, so the woman must leave it to go to hers, making her efficient, and also rewarding her with the dignity of a workplace without allowing her to leave the home. Frederick's production-based rhetoric appealed to the communists May and Lihotzky, and they eagerly set about trying to transform her theories into social reality, using space to enforce this distinction, as can be seen in Figure 1. 


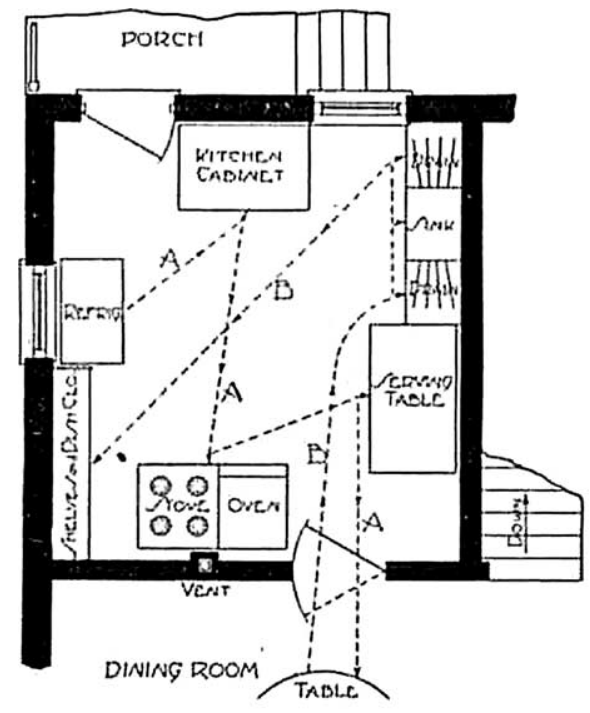

BADH GROUPED KITCHIAN RQUTPMEN'

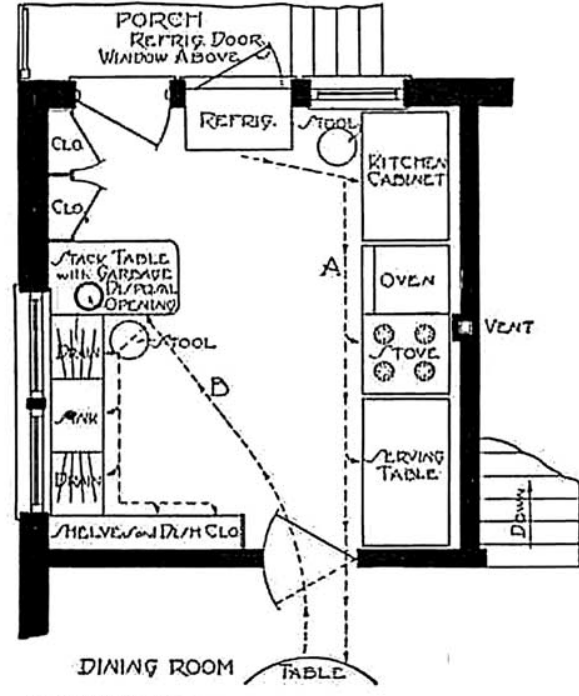

EFFICINAT GROUPING OF KITCHEN EQUTPMENT

A. Proparing route. B. Clearlng uwny route.

FIGURE 4 Left, Christine Frederick's model of an inefficient kitchen. Right, her model of an efficient 'workshop kitchen', which would save miles of walking and much wasted energy.

\section{Liberating women, segregating women: Frankfurt}

Yet May and Lihotzky's understanding of Frederick was faulty. Despite the fact that in Frederick the woman is (almost) never referred to as anything but the worker, despite the fact that the whole rhetorical emphasis is on liberation and production, on the housewife becoming 'a productive citizen of the State, not a social debtor', ${ }^{25}$ the real clue to what Frederick was arguing lay in one subsection of one chapter - but it was a theme to which she would return and dedicate the rest of her professional life. Frederick was a conservative trying to 'rescue' the women's movement in the USA from the 'Red Web' hysteria which threatened to obliterate it in the early 1920 s. $^{26}$ Whereas the book is dominated as a whole by talk of the woman as worker, as urban, as productive - all words guaranteed to draw in the most avant-garde, Heroic Modernist architects - there is a brief section called 'The housekeeper as trained consumer', in which Frederick argued:

Never before in the history of the family have the burdens of purchasing been placed so heavily on woman's shoulders. This is because today the modern woman is chiefly a consumer, and not a producer. ...To become a trained consumer is therefore one of the most important demands made on the housekeeper today. ... Also it may be said here, that every woman should be a trained consumer, whether she has a family (i.e., husband or children) or not. ${ }^{27}$

In this astute analysis she revealed her true colours, ones which would have appalled May and Lihotzky - although Penny Sparke has argued that the entire Modernist techno-aesthetic project was about instrumentalizing women and defeminizing the 
home. ${ }^{28}$ Frederick did not actually conceive of the woman in the kitchen as a unit of production, but of consumption, marking out the transition between the industrial and monopolistic phase of capitalism. Her major work of 1929, Selling Mrs. Consumer, was dedicated to Herbert Hoover, 'do nothing' president of America's slump years, and the work was targeted at advertisers and marketing managers. ${ }^{29}$ It sketched the psyche of the woman as Frederick saw it, replete with theories of suggestibility, passivity and inferiority complexes. Rereading Scientific management in the bome in the light of this work, and Dolores Hayden's analysis of it, transforms the 1920 book from a self-help course into an advertising catalogue. Indeed, both Frederick and Lillian Gilbreth made their fortunes in the 1920s through promoting certain products in their books and magazine articles while feigning scientific detachment. Frederick summed up in 1929:

Consumptionism... is the greatest idea that America has to give to the world; the idea that workmen and the masses be looked on not simply as workers or producers but as consumers. ${ }^{30}$

May and Lihotzky would have been outraged, but their misreading of Frederick went deeper than their glossing over that one subsection, or their obliviousness to the lists of approved brand names. Where German planners read production, and saw the liberation of women from premodern family structures, Frederick actually argued for something quite different. She wanted her planned kitchen to be a bare shell - a space the woman planned herself, compelling her to perform and invest in the role of housewife, so that she might fill it with products she had bought. She never envisioned it as a ready-made, socially provided unit, over which the woman had no say. It was to be a repository of, and assistant to, consumer capitalism, not the symbol of socialized production and the social state. If a municipality installed the whole thing, there would be no room to buy the gadgets - electrical gadgets in particular - on which she felt the whole future of the American economy, and actually therefore all of civilization, rested. These ideas underpinned debate about social housing in Germany - sometimes without being explicitly acknowledged.

With both socialist and capitalist inflections, this rhetorical model was widely propagated in Germany in the 1920s. However, the Frankfurt kitchen did not reign as supremely as the literature might imply; there were other spatial models which proved more capable of satisfying the rationalizing impulse, while enforcing very different familial arrangements. Metaphors of science and liberation permeated women's magazines, newspapers, trade journals and the popular press, and were frequently deployed in order to legitimize the radical rearrangements of women's lives. And yet many working-class women resisted this model of liberation with vigour - and Attfield, Miller and Freeman have explored some of the aesthetic, social and spatial models of this resistance in their work, exposing the gendered, ethnicized and class-based ways that resistance might express itself. ${ }^{31}$ While wealthier working-class Germans aspired to have a parlour for 'best', most could not afford it. Investigations in 1927 indicated 4.24 people per dwelling in Munich, with $29.3 \%$ of the city population living in one- or two-room dwellings, and a further $22.6 \%$ living in three rooms. ${ }^{32}$ Munich was entirely typical. The 'problem' of the parlour, therefore, cannot have been very real amongst Germany's poor. And yet the parlour for 'best' (the gute Stube) loomed large in the 
writings of countless household reformers like Lihotzky, Meyer and Witte, because it symbolized to them the aesthetic vulgarity of the working classes - and offered a way of intervening in their lives through the so-called 'feminine' aspects of taste in the home. Building 'tasteful' furniture into the home was a way of stopping working-class women moving 'crass' furniture in. ${ }^{33}$

But here was a problem. The attempt to force women to behave in a certain way undermined the liberationist credentials of the Frankfurt model, and the aesthetic underpinning of Lihotzky's arguments begins to make this spatial segregation seem more and more like an act of aggression against working-class women than act of liberation. Contemporary critiques of the Frankfurt kitchen were diverse, but the end effect of each was to tend towards the Munich solution. Adelheid von Saldern has shown that working-class women in Germany perceived the rational household not as a series of aesthetic decisions and ergonomic calculations, but as a household which practised birth control. ${ }^{34}$ Christina Benninghaus also confirms that the backbreaking nature of women's and girls' domestic work was often perceived to be of value in itself, demonstrating love and dedication to the family. ${ }^{35}$ Just how much some experts got it wrong has been well explored by Karen Hagemann in her oral history projects. Whereas 'experts' privileged what they considered to be rational arrangements of space, women themselves used complicated spatial and visual arrangements as a way of asserting their status amongst neighbours. A house which was 'homely' (namely, full of knick-knacks, curtains, rugs, pictures, plants, furniture and the like, all requiring dusting, cleaning and polishing) staked a claim to be considered bürgerlich, or middleclass, and thereby offered the housewife greater stature in her Hof (courtyard). A house which was difficult to manage, yet which was managed well, demonstrated that the woman was not a sloven, and that she did not have to work outside it. Sometimes, those who did work outside or who took work in disguised this fact from others and their husbands through elaborate housekeeping rituals, thereby allowing them to maintain control over their secret earnings. ${ }^{36}$

\section{Liberating women, socializing women: Munich}

The rationalizing model was far from all-conquering, either in the 1920 s or since despite Lihotzky's assurance in the 1980s or 1990s, when she was writing her memoirs, that 'today this is still surely the most desirable way to organize life in mass housing'. ${ }^{37}$ Many were dissatisfied with both these discourses. Whether a consumer or a producer, the woman in the Frederick/Lihotzky model is conceived of in the framework of a Marxian, materialist dialectic, or a consumerist/capitalist one. Munich, like Frankfurt, was committed to a massive housing programme. However, whereas May and the Frankfurt city government saw the 'open plains' of the aesthetic and productive postrevolutionary order as the antidote to social unrest and cultural malaise, and a (quasi-)scientific paradigm as the best way of achieving it, the Munich city government rejected, fundamentally, any idea that the worker, or the woman-as-worker, were commodities or instruments. Munich's governors and urban planners could not 
reconcile themselves to expensive experimentation with the means of production, relying instead on the pre-existing corporate capitalist structures of the German construction industry for the material aspect of the building programme. They rejected the May system of socialized prefabricated building partly because it was too expensive, but largely because it constructed women as productive units, needing rational scrutiny.

In contrast to the Frankfurt kitchen, the Munich kitchen was joined onto the living room, but at the same time offered many of the facilities of the fitted variety. This kitchen is in fact not really a kitchen at all. In German it is called a Kochnische, or a 'cooking niche'. It is an extension of the living room, and there is no barrier between the social world of eating and family life and labour world of food preparation and household administration. This feature, seen in Figure 2 in a mass housing project, is to be found in all of Munich's social housing projects of the late 1920s. It was no less determinist, no less resolute in its enforcement of certain social arrangements than the Frankfurt arrangement, but it was predicated on a model of working-class womanhood which ascribed greater agency to women in the management of their lives.

The Munich kitchen offered several advantages, both practical and ideological; most notably it was cheaper and smaller. But it also allowed the city to challenge the commodification of women as productive units by making a spatial elucidation of their central spiritual, social place in the home, a spiritual significance which demanded spatial organization. Lastly, it also overcame the resistance to resettlement, frequently seen in projects in Frankfurt, as it allowed a flexibility of space great enough to enable families to accommodate what little kitchen furniture they might own, if they wished. Residents of May's Frankfurt estates commented on this to a study party of the Munich corporation; and in Munich's designs, every effort was made to emphasize the housewife's own capacity to organize her domestic space, within parameters established by the city government. ${ }^{38}$ When the Munich party went to Frankfurt, they made a request to interview housewives there, a request which May did not fulfil. So some of the party seem to have interviewed the women behind May's back. This was a remarkable thing for experts to do at this time, and heightens their claim to be more responsive to women's own wishes. These women had a long list of charges that this kind of housing had diminished their freedoms, and when it came to kitchens, they particularly complained that they could not talk to their families or friends while working, nor could they bring their furniture with them from their old flats. Munich's Socialist Housing Director Preis argued:

The leading role in small flats must be given to the Wohnkïche, the opposite of the opinion put forward elsewhere, which argues from health and other grounds that the Frankfurt kitchen is to be preferred, a view rejected in Munich. In opposition the Münchener argues that it is in the character of the German whenever possible to be in company... ${ }^{39}$

One could hardly argue that this was an especially German characteristic. Given the deep rhetorical significance of efficiency, of engineering the 'new woman', and of American production paradigms and feminist discourses, the problem for Lihotzky's 
opponents was what vision of modernity - economic, spatial, gendered - should be put in its place.

To answer this, I need to turn to the huge exhibition organized by the municipality of Munich to promote its housing policies, and which should be seen as an adjunct to its housing programme. The exhibition, Ausstellung 'Heim und Technik' - 'Home and Technology' Exhibition - set out to promote the city's new mass housing policy amongst its own councillors and citizens, and challenge Stuttgart's Werkbund exhibition of the year before. It was planned in chronological parallel to the unfolding of the large-scale housing plans of the ' 12000 Homes Programme' in 1927/8. It was a huge success, attracting three times as many visitors as the 1927 Werkbund Weißenhof housing exhibition in Stuttgart, and thousands of column inches in the German press. ${ }^{40}$ In contrast to Stuttgart's primacy of aesthetics and exteriors (and comfortable place in narrating the rise of Heroic Modernism), the Munich exhibition explicitly intended to formulate clearly how a flat should function internally, and has been ignored by historians. Its aim was to define what the modern dwelling and the modern woman's relationship to technology, science and industry should be.

The exhibition was organized with walkways above and through 30 apartment interiors, including five designed for the 'new' single woman. Overall, it was a huge financial and media success. The exhibition was organized by the municipal building department, and in planning it, key figures in the council stated their views on women's place in the world, and how the home should define it. There were, it is true, appeals to a sort of 'elemental' home and an essentialist view of women, but they were always accompanied by an attempt to integrate that vision into an idea of the modern, the new era, the new human being which Modernists were so keen on engineering. In short, they liked the idea of engineering futures, but disliked the models which Frankfurt, and the underlying focus on rational scrutiny, implied. The city explicitly rejected International Movement paradigms, such as Le Corbusier's famous dictum that a home was a machine for living:

The so-called modern building method will be for us, therefore, not so much a stylistic as a practical question... The impact of the [council's] buildings ... will not stem from the idea of the 'machine for living', but from the demands of developing a sense of belonging and family. ${ }^{41}$

One of Munich's mayors, Karl Scharnagl, ${ }^{42}$ wrote on the opening page of the exhibition catalogue:

Home and technology - two words which encompass two fundamentally different worlds. Fundamentally different in the meaning of their very nature, in their significance for each and every one of us, in the effects which they have on human society. But they are also synonymous in this sense: they reach out to every modern person, they grasp him, and force him to take a position. ... What technology can achieve in the completion of the home must be constantly shown to us, and most especially to women, the very soul of the home. The City of Munich is fully aware of this, and is currently engaging itself in the tricky task of showing how to use technology for the completion of the home, and at the same time do justice to the diverse relationships inherent in the social organization of this city. ${ }^{43}$

Scharnagl seemed to recognize that home and technology might be constructed as binary opposites - as, perhaps, tradition vs. modernity, the warm vs. the cold, the 
comforting vs. the threatening, the living room versus, rather than integrated with, the kitchen. He also suggested - as did Frederick - that the residential unit is a place of encounter for the woman between what Frederick called 'unfeminine' technology on one side ${ }^{44}$ and the 'traditional' home (whatever that might be) on the other. As such he felt it worthy of particularly close governmental supervision. This was an encounter which was not to take place unchaperoned; space would be that chaperone. The city had an obligation, in the mayor's analysis, to make sure that woman remained the soul of the home. This was reflected spatially in the Munich kitchen, in the efforts of the council to place the soul at the heart of the body, rather than topographically removed. The city's plans acknowledged the ambition of governmental intervention to secure this goal, but, unlike the 'functionalist' approach, admitted a level of diversity not allowed in the Frankfurt model. This appeal to reflecting and empowering social diversity was a consistent feature of all of Scharnagl's speeches and writings on the built environment, and diverged sharply from the classic Heroic Modernist idiom. Whereas May and other Modernists predicated their vision on typification - building for the worker, the mother - Munich city council deliberately and explicitly built homes for different types of workers existing in different social contexts in different parts of the city. 45

One might question whether Munich's mass housing programmes genuinely accommodated this desire to control the city, and at the same time appeal to its social diversity. On balance, however, Bauamtmann Joseph Jelinek, the 'Home and Technology' exhibition organizer and himself a municipal architect, best summed up the overall municipal attitude. He described a Vernunftehe, a 'marriage of reason', between home and technology. He started by arguing that technological progress and rational planning in housing might mean the end of slavery for women - just as Catharine Beecher, Christine Frederick, Ernst May and Grete Lihotzky had done - but he also asserted, as did Beecher and Frederick, that 'the strongest cradle of the soul [Gemütes] is the home. The woman is its protector'. ${ }^{46}$ She could not be commodified or instrumentalized in a modern sense; her labour was not divisible. The elemental mother would be freed by technology, and by the Fordist, capitalist, rational planning paradigm, to stand watch over the home as a whole organism, not to be separated from it. Jelinek appealed to a sense of freedom; he announced through the introduction of science and technology into the home the emancipation of women, and trumpeted the end of their slavery - but then backtracked significantly:

The housewife still has a lot to do - potatoes will never peel and boil themselves. We have not come that far - and we never will, and we never want to. Because it is the joy of the bousewife to create in the bome, to organise her home berself, to make it homely and cosy. ... The housewife loves to have flowers at the window, not just because they are beautiful, because they decorate the home, but because she is related to their female nature. In the life of flowers, natural laws reign. The world of technology is also ruled by natural laws. Both, then, flowers and technology, have the same basics. In the flower, however, lies something else, something outside the laws of nature, something unattainable, a something which will always defy definition, call it life force, soul, spirit, feeling or what you will. And it is this something which is related to the nature of woman, this something which distinguishes flower and woman from the grandest and smartest gadgets which technology has produced. ${ }^{47}$ 
It should perhaps be pointed out that the affinity of women and flowers may well not have been a reference to the decorative value of women, but to the strongly grammatically feminine nature of 'flowers' in German. The arguments of these municipal councillors and technocrats directly echo the charge made more recently by Sparke that Modernism was a vigorous attempt to 'eliminate women's increased authority in the marketplace by condemning and devaluing the alliance between aesthetics, the feminine and commercial culture' ${ }^{48}$ The planning of the exhibition at every level often deployed a rhetoric of 'the woman as creator' - as did many others in Germany at the time, like architect Bruno Taut and sociologist Ludwig Neundörfer. For Jelinek, who organized the exhibition for the city of Munich, woman was firmly contextualized as an elemental, inscrutable figure whose social role was indivisible, just like the linearity of time which underpinned human experience. She was rational, in that (like flowers) she followed natural laws, but these laws should remain unstated, untested. She could not be conceptually separated from the social life of the home, and this conceptual proximity between work and social roles could be structured, and even enforced, by spatial means. At the same time, however, technology and capitalist analytic structures - cold modernity, perhaps - might assist her in her mission to protect the domestic world. A well-planned Kochnische would also save her time and energy, allowing her to devote herself more completely to her social roles. She is, in Scharnagl's analysis, the soul of the home, and in Jelinek's vision she is the fulcrum of a material world of technology and science on the one hand and an unnameable, irreducible realm of deep meaning and significance on the other.

The great Modernist quest for some sort of unity between head and heart, rational and elemental, is played out here. The burghers of Munich (and all the German cities which followed them), unlike those of Frankfurt, seem to have been committed to finding a reconciliation and a solution, rather than new ways of expressing and enforcing a demarcation. Through resisting the Frankfurt model, the Münchener hoped to find a synthesis which would reconcile the benefits of modernity, rational planning and social provision with the positive features of what they assumed to be a premodern, elemental society, characterized, they felt, by the domestic role of the woman. It was to be a rationally planned, technologically competent traditionalism, if that is not too great a paradox. It was a modern solution, and space was its coercive agent.

In Munich, the woman was spatially defined - by the removal of a wall - as primarily social and familial, not productive and functional. Her work environment was inseparable from her social role as a mother and a friend to visitors, and was not to be described symbolically in terms of industrial paradigms, whether in the consumptionist discourses of corporate America (Frederick) or the productivist ones of Soviet Russia (May). Munich city council wanted to define the best of the factory, and put it into the service of an idealized, elemental home and an essentialist view of woman. The personal and social roles of women as mothers and family members was privileged over their more impersonal ones as domestic managers, while allowing the economic, spatial and cooking advantages of rational planning to be fully exploited. The fusion of living and cooking space which Munich did not invent, but which they invested with 
modern, social, helping rhetoric, in fact turned out to be the more popular model in modern housing.

Like Beecher, Frederick, May and Lihotzky, Munich council's leaders, planners and architects were informed by their preconceptions of the nature of a built cultural artefact, the determining possibilities of space, their basic assumptions about what it meant to be a poor woman, and their underlying assumptions about advanced capitalist modes of production and the division of labour. But it appears that the committed revolutionary communism of May and Lihotzky, and the folksy nostalgia of the quasi-rural settlements favoured by those on the far right, were viewed by many councillors and experts as implausible and unrealistic solutions to the difficulties posed by modern social and cultural organization. Crucially, one can only arrive at this picture once historians have begun to accept, and therefore to research, the coercive (and not just suggestive) nature of space, and emphasize the often peripheral (and not mainstream) nature of Modernism.

\section{Acknowledgements}

Many thanks to all the people who have helped me with this article, especially Rachel Rich and Berthold Schoene. I would also like to thank the referees who pointed to further reading that was genuinely interesting and helpful.

\section{Notes}

${ }^{1}$ See e.g. Mark Wigley's psychoanalytically inspired analysis of two canonical works on building homes and producing order in domestic space, 'Untitled: the housing of gender', in B. Colomina, ed., Sexuality and space (New York, Princeton Architectural Press, 1992), pp. 327-89.

2 E.g. Sharon Marcus's discussion of novels and the lobbies of apartment buildings, Apartment stories: city and home in nineteenth century Paris and London (Berkeley, University of California Press, 1999); Lynda Nead's use of songs to analyse a pleasure garden, Victorian Babylon: people, streets and images in nineteenth-century London (London, Yale University Press, 2000).

3 L. Lees, 'Urban geography: discourse analysis and urban research', Progress in human geography 28 (2004), pp. 101-7; 'Rematerializing geography: the "new" urban geography', Progress in human geography 26 (2002), pp. 101-12; C. Philo, 'More words, more worlds: reflections on the cultural turn in human geography', in I. Crouch et al., eds, Cultural turns/ geographical turns: perspectives in cultural geography (Harlow, Prentice Hall, 2000); P. Jackson, 'Rematerializing social and cultural geography', Social and cultural geography 1 (2000), pp. 9-14.

${ }^{4}$ H. Heynen, Architecture and modernity: a critique (London, MIT Press, 1999); P. Rowe, Modernity and housing (Cambridge, MA, MIT Press, 1995); P. Gay, Weimar culture: the outsider as insider (London, Penguin, 1974); J. Willett, The new sobriety: art and politics in the Weimar period (London, Thames \& Hudson, 1978); D. Peukert, The Weimar Republic: the crisis of classical modernity (London, Penguin, 1991). 
5 P. Betts, The authority of everyday objects: a cultural history of West German industrial design (Berkeley, University of California Press, 2004).

${ }^{6}$ For example, in Thomas Markus's excellent Buildings and power: freedom and control in the origins of modern building types (London, Routledge, 1993), plans of both 'real' and 'ideal' buildings are shown. However, real and ideal are ascribed equal importance, and producers' rhetoric surrounding the plans is privileged at the expense of how they must have intervened in people's lives.

7 I. Cieraad, 'Anthropology at home', in Cieraad, ed., At home: an anthropology of domestic space (Syracuse, NY, Syracuse University Press, 1999), pp. 1-12.

8 M. Llewellyn, 'Designed by women and designing women: gender, planning and the geographies of the kitchen in Britain, 1917-1946', Cultural geographies 11 (2005), pp. 42-60.

9 E. Blau, The architecture of Red Vienna (London, MIT Press, 1999), pp. 182-87.

${ }^{10}$ May was far from the only 'hero' of Modernist architecture to be so; the word 'Taylorism' appears in all of Le Corbusier's works of the 1920s and 1930s. M. McLeod, 'Architecture or revolution: Taylorism, technocracy and social change', Art journal 2 (1983), pp. $132-47$.

11 C. Frederick, Household engineering: scientific management in the bome (London, Routledge, 1920 [Chicago, American School of Home Economics, 1919]); first German edn Die rationelle Haushaltsführung: Betriebswissenschaftliche Studien, trans. I. Witte (Berlin, 1922).

12 G. Kuhn, Wohnkultur und kommunale Wohnungspolitik in Frankfurt am Main, 1880-1930: Auf dem Wege zu einer pluralen Gesellschaft der Individuen (Bonn, Dietz, 1998), pp. 142-76; G. Schütte Lihotzky, Warum ich Architektin wurde (Salzburg, Residenz Verlag, 2004), p. 153; M. Nolan, 'Housework made easy: the Taylorized housewife in Weimar Germany's rationalized economy', Feminist studies 3 (1990), pp. 549-77; R. Pokorny, 'Die Rationalisierungsexpertin Irene M. Witte (1894-1976): Biografie einer Grenzengängerin' (doctoral dissertation, Technische Unversität Berlin, 2003), pp. 80-88.

13 L. Kramer, 'Rationalisierung des Haushaltes und Frauenfrage - Die Frankfurter Küche und Zeitgenössische Kritik', in H. Klotz, ed., Ernst May und das neue Frankfurt, 1925-1930 (Berlin, Verlag für Architektur und Technische Wissenschaften, 1986), pp. 77-84.

${ }^{14}$ A trend first outlined by Barbara Welter in the 1960s: 'The cult of true womanhood', American quarterly 18 (1966), pp. 151-74; she enlarges her thesis in Dimity convictions: the American woman in the nineteenth century (Athens, Ohio University Press, 1976), pp. $21-41$.

15 C. Beecher, A treatise on domestic economy for the use of young ladies at home and at school (Boston, Marsh, Capen, Lyon \& Webb, 1841), pp. 121-34, 268-98, and esp. 366-70, 'On the importance of a convenient kitchen'; C. Beecher and H. Beecher Stowe, The American woman's home, or, Principles of domestic science (New York, J.B. Ford, 1869).

16 See V. Gill, 'Catharine Beecher and Charlotte Perkins Gilman: architects of female power', Journal of American culture 2 (1998), pp. 17-24; D. Hayden, The grand domestic revolution: a history of feminist designs for American homes, neighborboods, and cities (London, MIT Press, 1981), esp. pp. 55-63.

17 M. Nolan, Visions of modernity: American business and the modernisation of Germany (Oxford, Oxford University Press, 1994).

18 Literature promoting this phenomenon is easily to be found in the public libraries of industrial towns in Britain. A good introduction to the basic principles can be found in F. Gilbreth and L. Gilbreth, Applied motion study: a collection of papers on the efficient method to industrial preparedness (New York, Sturigs \& Walton, 1917). Lillian's application of them to the home are 
analysed in L. Graham, 'Domesticating efficiency: Lillian Gilbreth's scientific management of homemakers, 1924-1930', Signs: journal of women in culture and society 3 (1999), pp. $633-75$.

19 S. Kern, The culture of time and space, 1880-1919 (Cambridge, MA, Harvard University Press, 1983).

20 R. Barnes, Motion and time study, 2nd edn (New York, Wiley, 1940), p. 15.

${ }^{21}$ Cited in D. Gross, 'Space, time and modern culture', Telos 50 (1981-82), pp. 59-78.

${ }^{22}$ Frederick, Household engineering, p. 7.

23 Ibid. p. 19.

24 Ibid. p. 34.

25 Ibid. p. 381.

${ }^{26}$ For a good analysis of this phenomenon, see Hayden, Grand domestic revolution, pp. 280-89.

27 Frederick, Household engineering, pp. 316-17 (emphasis original).

28 P. Sparke, As long as it's pink: the sexual politics of taste (London, Pandora, 1995).

${ }^{29}$ Hayden, Grand domestic revolution, pp. 281-87; J. Rutherford, Selling Mrs. Consumer: Christine Frederick and the rise of household efficiency (Athens, Georgia University Press, 2003), pp. 121-35, 146-57.

30 Cited in Hayden, Grand domestic revolution, p. 286.

31 D. Miller, 'Appropriating the state on the council estate', Man 2 (1988), pp. 353-72; J. Attfield, 'Bringing modernity home: open plan and the British domestic interior', in Cieraad, At home, pp. 73-82; J. Freeman, The making of the modern kitchen: a cultural history (Oxford, Berg, 2004).

32 Wohnungsreferent Karl Preis, Die Beseitigung der Wohnungsnot in München: Denkschrift und Anträge (Munich, Landeshauptstadt München, 1927), p. 12.

33 Adelheid von Saldern, 'Social rationalization of living and housework in Germany and the United States in the 1920s', History of the family 2 (1997), pp. 81-83. See also Sparke, As long as it's pink.

${ }^{34}$ Saldern, 'Social rationalization', pp. 87-89.

35 C. Benninghaus, 'Mothers' toil and daughters' leisure: working-class girls and time in $1920 \mathrm{~s}$ Germany', History workshop journal 50 (2000), pp. 45-72.

${ }^{36}$ K. Hagemann, 'Von "guten" und "schlechten" Hausfrauen: Möglichkeiten und Grenzen der Rationalisierung im großstädtischen Arbeiterhaushalt der Weimarer Republik', Historische Mitteilungen der Ranke Gesellschaft 8 (1995), pp. 65-84; Frauenalltag und Männerpolitik: Alltagsleben und gesellschaftliches Handeln von Arbeiterfrauen in der Weimarer Republik (Bonn, Dietz, 1990), esp. pp. 106-14 on household reform.

37 Lihotzky, Warum ich Architektin wurde, p. 147.

38 Bericht über die Reise der Mitglieder der Stadtratskommission beim Wohnungsamt nach Nürnberg und Frankfurt a. M. vom 22.-24. November 1926. Stadtarchiv München [SAM]Wohnungsamt [WA]-63; Jahresbericht des Vorstandes der Gemeinnützigen Wohnungsfürsorge AG München, 1928, p. 8. SAM-Bürgermeister und Rat [B\&R]-1458.

39 Preis, Die Beseitigung der Wohnungsnot in München, p. 14.

40 Which dominates the historiography of building this period, and which the Munich exhibition deliberately set out to challenge. See R. Pommer and C. Otto, Weißenhof 1927 and the modern movement in architecture (London, Chicago University Press, 1991), and the excellent bibliographical details there.

${ }^{41}$ Gemeinnützige Wohnungsfürsorge AG München, Die Siedlungen der Gemeinnützigen Wohnungsfürsorge AG München (Munich, Gemeinnützige Wohnungsfürsorge AG München, 1928), p. 6. 
42 Bavarian cities in this period always had two mayors, one elected and one appointed by the government.

43 K. Scharnagl, 'Geleitwort', in Amtlicher Katalog: Ausstellung 'München 1928: Heim und Technik' (Munich, Hochbauamt, 1928), p. 13.

${ }^{44}$ Frederick, Household engineering, p. 84.

45 This position was most fully elaborated in Referat VII [Wohnungsreferat], Principles for judging the bousing question [in English], 1930, SAM-B\&R-993.

46 J. Jelinek, 'Die Vernunftehe Heim \& Technik', in Amtlicher Katalog: Ausstellung 'München 1928: Heim und Technik', p. 75.

47 Ibid. (emphasis added).

48 Sparke, As long as it's pink, p. 22. 